\title{
The correlation between self-efficacy and motivation on elderly's daily independence
}

\author{
Indra Setia $\mathbf{W}^{\mathbf{1}}$, Nur Isnaini ${ }^{\mathbf{2}}$ \\ ${ }^{1,2}$ Department of Health, Muhammadiyah University of Purwokerto, Indonesia
}

\begin{tabular}{l} 
ARTICLE INFO \\
\hline Article history: \\
Received: August 9, 2020 \\
Revised: August 20, 2020 \\
Accepted: August 30, 2020 \\
\hline
\end{tabular}

\section{Keywords:}

Self-efficacy, Motivation, elderly's daily independence, Elderly Social Service

\begin{abstract}
Being old is a condition that happens in life and means experiencing a physical and psychological decline. Generally, it means experiencing weakness, limitation, and inability which affect one's life quality. Self-efficacy is closely related to independence, meaning that the higher self-efficacy the higher the ability to manage behaviour or independence will be. Independence in the elderly is affected by psychological energy, which depends on the level of motivation. The elderly having high motivation tends to be passionate. He/she is different from those having no motivation, who tend to be lazy and less understand the importance of health. This research to identify the correlation between self-efficacy and motivation on elderlies independence at Sudagaran Elderly Social Service House in Banyumas District. This research is a quantitative research using analytical observational design with a crosssectional approach. The research sample consisting of 71 elderly people at Sudagaran Elderly Social Service House in Banyumas District were taken through purposive sampling. The research instrument was a questionnaire sheet. It was analysed using Chi-Square test. Most of the respondents are female $(55.3 \%)$, have medium self-efficacy level (78.9\%), have medium motivation level (67.7\%), and are categorized independent (57.7\%). The result of Chi-Square test for the self-efficacy obtains p-value of $0.002=0.05$ and for the motivation obtains $p$-value of $0.022=0.05$ on the elderly's daily independence. There is a correlation between self-efficacy and motivation on elderly's daily independence at Sudagaran Elderly Social Service House in Banyumas District.
\end{abstract}

This work is licensed under a Creative Commons Attribution 4.0 International License.

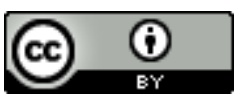

\author{
Corresponding Author: \\ Nur Isnaini, \\ Department of Health, Muhammadiyah University of Purwokerto, \\ Soepardjo Rustam Street KM. 7, Banyumas, Indonesia \\ Email: nurisnaini@ump.ac.id
}

\section{INTRODUCTION}

Aging or getting old is a condition that occurs in human life. The process of aging is a lifelong process, not only starting at a certain time, but starting at the beginning of life. Entering old age means experiencing a setback, for example a physical deterioration characterized by sagging skin, gray hair, tooth loss, less clear hearing, worsening vision, slow motion, disproportionate body figure. [1]

The number of elderly people in Indonesia has increased every year. The increase in the number of elderly people also has an impact on increasing the life expectancy in Indonesia. The Central Bureau of Statistics (BPS) also said that there was an increase in life expectancy, from 64.5 years (with a percentage of the elderly population of $7.18 \%$ ) in 2000 to 69.43 in 2010 (with a percentage of the elderly population of 7.56. $\%$ ), and in 2011 it became 69.65 years (with a percentage of the elderly population of $7.58 \%$ ) (Center for Data and Information, Ministry of Health of the Republic of Indonesia, 2013). In 2017 the percentage of lans in Central Java reached 12.59 and then increased to $13.03 \%$ of the population in the following year, namely 2018 with a total of 4.49 million. And Banyumas in 2018 occupies the second position with the largest number of elderly people with 236.2 thousand of the population of 1.691 thousand. The increasing proportion of elderly people has caused several health problems in the elderly (Pusat Data Statistik 2018). According in the elderly 
there will be a decrease in strength by $88 \%$, hearing $67 \%$, vision $72 \%$, memory $61 \%$, and decreased flexibility by $64 \%$. In general, the elderly face weaknesses, limitations and disabilities, which will affect their quality of life. [2] The quality of life of the elderly is the extent to which a person can feel and enjoy the occurrence of all important events in his life so that his life becomes prosperous. If a person can achieve a high quality of life, then the individual's life leads to a state of well-being, on the other hand, if a person achieves a low quality of life, then the individual's life leads to a state of not being prosperous. [3]

States that mental and cognitive disorders can cause dependence on the elderly which consequently causes physical mobility problems which will limit the independence of the elderly in fulfilling their daily activities. [4] Research on the level of independence of the elderly at the Tresna Werdha Senja Rawi Social Institution stated that most of the elderly as many as 15 people (72\%) were partially dependent, 3 people (14 $\%)$ including independent and 3 people (14\%) included in total dependence. [5]

Researchers conducted a preliminary study through interviews with officers and elderly people who were in that place and conducted tests using the Barthel Index. Then 4 out of 10 elderly people experience mild dependence. The results of the interview regarding the dependence of the elderly found that there were only 2 caregivers there. This shows that the number of caregivers is not proportional to the number of elderly people who are there where dependence has a relationship with efficacy and motivation.

\section{RESEARCH METHOD}

This research is a quantitative study, the design of this research is observational analytic, using a crosssectional approach. This research was conducted on January 21-24 2020 at the Sudagaran Elderly Social Service Center, Banyumas Regency. The population in this study were 89 elderly people who actively participate in posyandu activities. The sample of this study was 71 respondents who had met the inclusion and exclusion criteria.

The sampling technique in this study was using purposive sampling technique. The data collection tool in this study was a questionnaire sheet consisting of five parts. The first part contains the respondent's characteristic sheet (name, age, education and address), the second part contains the motivation questionnaire sheet using the Elderly Motivation Scale, the third part contains the self-efficacy questionnaire using the selfefficacy questionnaire which has been converted to valid and realiable Indonesian, the fourth part The elderly independence questionnaire sheet uses the Barthel Index ADLs.

Data analysis used is univariate analysis to determine the frequency distribution of respondent characteristics (gender, and education), and bivariate analysis to determine the relationship between independent variables (self-efficacy and motivation) with the dependent variable (level of independence). The research data were processed through the process of editing, coding, scoring, tabulating, processing and cleaning. The statistical test used is the Chi-Square test.

\section{RESULT AND DISCUSSIONS}

\subsection{Univariat}

Tabel 1. Frequency Distribution of the Elderly in the Social Service Center for the Elderly of Sudagaran Banyumas Regency

\begin{tabular}{lcc}
\hline Characteristics of Respondents & Frequency & Percentage \\
\hline Gender & 31 & \\
Male & 40 & $43.7 \%$ \\
Woman & & $55.3 \%$ \\
Education & 26 & $36.6 \%$ \\
No School & 30 & $42.3 \%$ \\
Primary School & 3 & $4.2 \%$ \\
Junior High School & 10 & $14.1 \%$ \\
Senior High School & 2 & $2.8 \%$ \\
College & 71 & $100 \%$ \\
\hline Total & & \\
\hline
\end{tabular}

Based on table 1 above, it is known that most of the respondents are female, namely 40 (55.3\%) respondents, and have an elementary school education (42.3\%) of respondents. 
Table 2. Frequency Distribution of Self-Efficacy, Motivation and Independence of the Elderly in the Elderly Social Service Institution of Sudagaran

\begin{tabular}{lcc}
\hline Variable & Frequency & Percentage \\
\hline Self Efficacy & & \\
Low & 12 & $16.9 \%$ \\
Moderate & 56 & $78.9 \%$ \\
High & 3 & $4.2 \%$ \\
Motivation & & \\
Low & 13 & $18.3 \%$ \\
Moderate & 48 & $67.6 \%$ \\
High & 10 & $14.1 \%$ \\
Level of Indepedence & & \\
Independent & 41 & $57,7 \%$ \\
Mild Dependence & 27 & $38 \%$ \\
Moderate Dependence & 1 & $1,4 \%$ \\
Heavy Dependence & 2 & $2,8 \%$ \\
\hline
\end{tabular}

Based on table 2, 12 respondents $(16.9 \%)$ had a low self-efficacy level, 56 respondents $(78.9 \%)$ had a moderate self-efficacy level, and 3 elderly $(4.2 \%)$ had a high self-efficacy level. The distribution of respondents seen from the motivation variable has a low motivation level of 13 respondents $(18.3 \%)$, and the elderly who have a moderate level of motivation are 48 respondents $(67.6 \%)$ and 10 elderly $(14.1 \%)$ who have a high level of motivation. While the distribution of respondents based on the independence variable, it is known that the elderly in the elderly social service center who have a level of severe dependence are 2 respondents $(2.8 \%)$, and the elderly who have a moderate level of dependence are 1 respondent (1.4\%), 27 elderly (38\%) who have a mild level of dependence and there are $41(57.7 \%)$ elderly in the independent category $(36.1 \%)$ of respondents. Medium dependence $2(1.7 \%)$ of respondents.

\subsection{Bivariat}

Table 3. Relationship between efficacy, motivation and level of independence

\begin{tabular}{|c|c|c|c|c|c|}
\hline \multirow[b]{2}{*}{ Variabel } & \multicolumn{4}{|c|}{ Independence } & \multirow[b]{2}{*}{ p-value } \\
\hline & $\begin{array}{c}\text { Severe } \\
\text { dependence }\end{array}$ & $\begin{array}{c}\text { Moderate } \\
\text { dependence }\end{array}$ & $\begin{array}{c}\text { Mild } \\
\text { dependence }\end{array}$ & Independent & \\
\hline \multicolumn{6}{|l|}{ Self Efficacy } \\
\hline Low & $100 \%$ & $100 \%$ & $3,7 \%$ & $19,5 \%$ & \\
\hline Moderate & 0 & 0 & $96,3 \%$ & $73,2 \%$ & 0,002 \\
\hline High & 0 & 0 & & $7,3 \%$ & \\
\hline \multicolumn{6}{|l|}{ Motivation } \\
\hline Low & $50 \%$ & $100 \%$ & $14,8 \%$ & $17,1 \%$ & \\
\hline Moderate & $50 \%$ & 0 & $85,2 \%$ & $58,2 \%$ & 0.022 \\
\hline High & 0 & 0 & 0 & $24,4 \%$ & \\
\hline
\end{tabular}

Based on table 3, it shows that the results of the chi square calculation of the relationship between self-efficacy, motivation and level of independence with quality of life in the elderly in the village of Sokaraja Kulon obtained $\mathrm{p}$ value $0.002 \& 0.022<\alpha(0.05)$ which means that it is significant and Ha is accepted. This means that there is a relationship between self-efficacy, motivation and level of independence at the Sudagaran Elderly Social Service Center, Banyumas Regency. There are 12 elderly (16.9\%) at the Sudagaran Banyumas Elderly Social Service Center who have a low level of efficacy with a severe level of dependence of 2 elderly $(100 \%), 1$ elderly $(100 \%)$ with moderate dependence and $1(100 \%)$ elderly with mild dependence and there were $8(16.9 \%)$ in the independent category. Furthermore, there were 26 elderly people $(96.3 \%)$ who had moderate self-efficacy levels with low dependence, as many as 30 elderly (73.27\%). In addition, there are 3 elderly (7.3\%) with high self-efficacy with a level of independence in the independent category. There are 13 elderly $(16.9 \%)$ at the Sudagaran Banyumas Elderly Social Service Center who have a low level of efficacy with a severe level of dependence as much as 1 elderly (50\%), 1 elderly (100\%) with moderate dependence and $4(14.8 \%)$ elderly with mild dependence and there were $7(17.1 \%)$ in the independent category. Furthermore, there were 48 elderly people $(67.6 \%)$ who had a moderate level of motivation with a severe level of dependence as many as 2 elderly (50\%), 24 (85.2\%) elderly with mild dependence and there were $24(58.5 \%)$ 
with the independent category. In addition, there are 10 elderly (24.4\%) with high self-efficacy with a level of independence in the independent category

\subsection{The relationship between self-efficacy and the daily independence of the elderly}

The results of the study on the variable self-efficacy with 71 respondents showed that the majority of the elderly at the Elderly Social Service Institution who had a low level of efficacy with a severe level of dependence were 2 elderly (100\%), 1 elderly (100\%) with moderate dependence and $1(100 \%)$ elderly with mild dependence and there were $8(16.9 \%)$ in the independent category. Furthermore, there were 26 elderly people $(96.3 \%)$ who had moderate self-efficacy levels with low dependence, as many as 30 elderly (73.27\%). In addition, there are 3 elderly $(7.3 \%)$ with high self-efficacy with a level of independence in the independent category.

Based on the bivariate analysis using a computer, it was found that there was a relationship between self-efficacy and the daily independence of the elderly. This is in accordance with the chi square test, the pvalue is 0.002 where the $\mathrm{p}$-value is $<0.05$ so that $\mathrm{Ha}$ is accepted, which means that there is a relationship between self-efficacy and daily independence for the elderly at the Sudagaran Elderly Social Service Center, Banyumas Regency.

Self-efficacy is self-assessment, whether you can do good or bad actions, right or wrong, you can or can't do something, this efficacy is different from aspirations (ideals), because ideals describe something that should be achieved, while efficacy describes self-assessment. [6]

The relationship between self-efficacy and daily independence in the elderly has a p-value of 0.002 which means there is a relationship. This is in accordance with the results of research on "General self-efficacy in elderly living in rest homes". [7] The data shows that the level of efficacy of a person is directly related to their level of education and the duration of being there and is related to gender. Owned by the individual is something that affects the individual in self-care. This belief is called self-efficacy. [8] According to state that self-efficacy is a belief in yourself and one's ability to do something behavior successfully. Someone who has high self-efficacy will be more likely to have confidence and ability to achieve desires according to their goals. The high level of self-efficacy in individuals cannot be separated from the factors that influence it.

The relationship between self-efficacy and daily independence in the elderly has a p-value of 0.002 which means there is a relationship. This is in accordance with the results which emphasized that the low selfefficacy score in social institutions shows that the authorities (orphanages) must pay more attention to the needs and demands of the elderly in the institution. [9]

In the opinion of the researcher, the efficacy will affect the independence of a person where someone who has a high willingness will affect the activities he carries out daily where here is the fulfillment of his daily activities.

\subsection{The relationship between motivation and independence on a daily basis in the elderly}

Motivation is a psychological characteristic that contributes to a person's level of commitment, this includes factors that cause channeling and maintaining human behavior in a certain direction. [10]

Based on the results of research on the motivation variable, the result shows that the majority of the elderly in the Elderly Social Service Center are moderate, with a total of 48 (67.6\%) respondents. Based on the bivariate analysis using a computer, the results show that there is a relationship between motivation and the level of daily independence in the elderly. This is in accordance with the Chi Square test, the Sig. (2-tailed) or p-value 0.002 where the p-value is $<0.05$ so that $\mathrm{Ha}$ is accepted, which means that there is a positive relationship between motivation and the level of daily independence of the elderly in the Elderly Social Service Institution. This research is in line with research which shows that there is a relationship between motivation and the independence of the activity of daily living ( $\mathrm{p}$ value 0.000 ). This shows that without inner motivation you will experience limitations in doing something. [11]

Motivation is a complex statement within an organism that directs behavior towards a goal or stimulus. [12] In addition,motivation is a personal condition in a person that encourages individual wants or needs in carrying out certain activities in order to achieve goals. [13] According to Vallerand and O'Connor,the motivation of the elderly is divided based on the activities carried out by the elderly and divided into six domains, namely health, biological needs, relationships with other people, religious activities, recreation, and 
the need for information. [14] In this study, there were some elderly who did not follow one of the domains, namely the recreation domain because of their physical and health limitations, and if there were no such limitations they always implemented it. In motivation is based on the knowledge possessed by the individual. Individuals will be motivated to take an action if something with a goal, plan and expected results. [15] This is supported by research which is that there is a relationship with self-care and is strengthened by previous research, that individuals who have high motivation will have good self-care.

The results of research A Study on IADL, Stress and Motivation on Healthy Lifestyle among Elderly People with Arthritis" show that there is a significant positive relationship between motivation and a healthy lifestyle and daily activities. [16] According to humans have 3 main passions which in this case are also called instincts. Namely, the instinct to defend itself develops and maintains the type, then the habits or actions and behavior of humans that they do everyday get encouragement or are moved by these three instincts. The dependence of the elderly is caused by the condition of the elderly who have experienced many physical and psychological setbacks. Meanwhile, when viewed from the level of independence which is assessed based on the ability to carry out daily activities. Lack of physical immobility is a problem that is often found in elderly patients due to various physical, psychological, and environmental problems experienced by the elderly. Immobilization can cause complications in almost any organ system. The mental health condition of the elderly shows that in general the elderly are unable to carry out daily activities. [17] The results of research conducted entitled "Quality of life and wellbeing of the elderly in Libanese. nursing homes "shows that mild depression rates are relatively high among the elderly and lack of mobility. In general, elderly residents who have normal functions are those who are well cared for and have moderate levels of daily activity. [18]

Researchers assume that a person's motivation will affect a person's independence where motivation serves as a motivation for someone to do something, without motivation someone will become lazy.

\section{CONSLUSION}

Most of the elderly who became respondents were female with a total of 40 elderly (55.3\%), while the number of men was 31 elderly (43.7\%). The educational level is mostly elementary school with 30 elderly $(42.3 \%)$, has a moderate level of self-efficacy as many as 56 elderly (78.9\%), moderate motivation is 48 elderly $(67.7 \%)$ and has a level of independent independence as many as 41 elderly (57.5\%). There is a relationship between self-efficacy and motivation on the daily independence of the elderly at the Sudagaran Elderly Social Service Center, Banyumas Regency with p values of 0.002 and 0.022 .

\section{Acknowledgements}

Thank you to Allah SWT, both parents and all comrades in arms who have helped from beginning to end.

\section{REFERENCES}

[1] Abiyoga, "Faktor-faktor Yang Berhubungan Dengan Kejadian Gout Pada Lansia Di Wilayah Kerja Puskesmas Situraja Tahun 2014," Jurnal Darul Azhar, vol. 2, no. 1, p. 47-56, 2017.

[2] M. Katuuk, "Hubungan Kemunduran Fisiologis Dengan Tingkat Stres Pada Lanjut Usia Di Puskesmas Kakaskasen Kecamatan Tomohon Utara,” Jurnal Keperawatan, vol. 6, no. 1, 2018.

[3] Risdianto, "Hubungan Dukungan Sosial dengan Kualitas Hidup Lanjut Usia di Desa Kembang Kuning Cepogo Boyolali.,” Skripsi Fakultas Ilmu Kesehatan Universitas Muhammadiyah Surakarta, tidak dipublikasikan, Surakarta, 2009.

[4] Nugroho, Keperawatan Gerontik \& Geriatrik, 3 penyunt., Jakarta: EGC, 2008.

[5] S. Rohaedi et al., "Tingkat Kemandirian Lansia Dalam Activities Daily," Pendidikan Keperawatan Indonesia, vol. 2, no. 1, p. 17, 2016.

[6] Priyoto, Teori Sikap \& Perilaku dalam Kesehatan, Yogyakarta: Nuha Medika, 2014.

[7] T. Y, “General Self Efficacy in Elderly Living in Rest Homes. Tehran. Iran,” Journal of Nursing.

[8] E. Irawan dan F. Amelia, "Hubungan Self Efficacy Dengan Perawatan Diri Lansia Hipertensi," vol. 2, p. 130-139, 2017.

[9] M. Heidari dan M. ghodusi, "Comparative Self Efficacy in Elderly and Non Elderly ResidentsOf Family and Nursing Home in Shahrekord. Shahrekord.," Quarterly Journal of Geriatric Nursing, 2015. 
[10] Nursalam, Metedologi penelitian ilmu keperawatan, 4 penyunt., Jakarta: Salemba Medika, 2015.

[11] A. Dwi, Arifianto dan Auliazardh, "Faktor faktor yang berhubungan dengan kemandirian activity of daily living ADL pada pasien post stroke di rehabilitasi medik RSUD Tuggurejo Semarang," Jurnal NERS Widya Husada, vol. 3, no. 1, 2016.

[12] Purwanto, Psikologi Pendidikan, Bandung: PT Remaja Rosdakarya, 2017.

[13] Gufron, Teori-Teori Psikologi, Ar-Ruzz Media, 2010.

[14] K. Putri, "Pengaruh Motivasi, Aktifitas dan Pemenuhan Tugas Pengembangan Terhadap Kepuasan Hidup Lansia Duda dan Janda,” IPB, BOGOR, 2015.

[15] V. Paskalini, "Hubungan Dukungan Sosial dan Motivasi Dengan Perawatan Mandiri Pada Pasien Diabetes Melitus Tipe 2 di Poliklinik Penyakit Penyakit dalam RSUD Nokopindo Toli Toli,” vol. 5, no. $1,2017$.

[16] . J. G. Kim, K. H. Moon, E. S. Lim dan J. H. Yoo, "[1 A Study on IADL, Stress and Motivation on Healthy Lifestyle among Elderly People with Arthritis.," Journal of the Korea Academia-Industrial Cooperation Society, vol. 17, no. 3, p. 209-217, 2016.

[17] D. Malida, "Faktor Yang Mempengaruhi Tingkat Kemandirian Lansia Dalam Melakukan Aktifitas Kehidupan Sehari - hari Di Panti Sosial Tresna Werdha Budi Luhur Kota Jambi,” Jambi, 2011.

[18] J. Doumit dan R. Nasser, "Quality of life and wellbeing of the elderly in Lebanese nursing homes.," International Journal of Health Care Quality Assurance, vol. 23, no. 1, p. 72-93, 2010. 